\title{
EVALUATION OF THE BUSINESS ENVIRONMENT OF PARTICIPATING COUNTRIES OF THE BELT AND ROAD INITIATIVE
}

\author{
Zheng-Xin WANG ${ }^{1}$, Wen-Qian $\mathrm{LOU}^{1^{*}}$, Ling-Ling PEI ${ }^{2}$ \\ ${ }^{1}$ School of Economics, Zhejiang University of Finance \& Economics, \\ 310018 Hangzhou, China \\ ${ }^{2}$ School of Business Administration, Zhejiang University of Finance \& Economics, \\ 310018 Hangzhou, China
}

Received 03 August 2019; accepted 01 July 2020

\begin{abstract}
As an important indicator for measuring the quality of business environment of different countries, ease of doing business (EDB) issued by the World Bank (WB) provides an important reference for investors in making decisions on transnational investment. The calculation method for $\mathrm{EDB}$ issued by the WB is improved using a technique for order preference by similarity to an ideal solution (TOPSIS) method based on Mahalanobis distance. Based on various indicator data in 2019, business environments in 121 countries participating in "the Belt and Road Initiative (BRI)" were empirically analysed and compared through such models. The result showed that TOPSIS method based on Mahalanobis distance can more fully utilise information and take the effect of negative ideal points into account. Therefore, compared with ranking method by the WB, TOPSIS method based on Mahalanobis distance is more applicable for ranking BRI countries. The ranking results indicated significant geographical characteristics. The EDB rankings obtained through the WB overestimate the business environments of countries in Central and Eastern Europe while underestimate those in Southeast Asia, Africa, etc.
\end{abstract}

Keywords: the Belt and Road initiative, TOPSIS, Mahalanobis distance, business environment.

JEL Classification: C63, F13, F41.

\section{Introduction}

"The Belt and Road Initiative" (BRI), as a major strategic measure for expanding openingup, was proposed by the Chinese Government in 2013. It aims to facilitate orderly and free flow of economic factors, efficient allocation of resources and deep integration of markets; drive coordination of economic policies of various BRI countries; carry out even boarder and more sophisticated regional cooperation; and foster a regional framework of open and inclusive economic cooperation (Yan et al., 2018). BRI has effectively facilitated China's in-

${ }^{\star}$ Corresponding author. E-mail: viwenqian@163.com

Copyright $\odot 2020$ The Author(s). Published by Vilnius Gediminas Technical University

This is an Open Access article distributed under the terms of the Creative Commons Attribution License (http://creativecommons. org/licenses/by/4.0/), which permits unrestricted use, distribution, and reproduction in any medium, provided the original author and source are credited. 
vestment and cooperation with BRI countries (Huang, 2019; Cullinane et al., 2018); however, investment risk will increase due to some problems of business environments of some BRI countries ( $\mathrm{Li}$ et al., 2019), including unstable political situations, disputes around resource utilisation and development, and frequent changes in regulations and policies $(\mathrm{Qu} \&$ Yang, 2017). Therefore, conducting comprehensive evaluation on business environments of various BRI countries by utilising scientific methods provides reference for enterprises in making decisions on transnational investment and also promotes BRI countries to improve their business environments to some extent.

In terms of business environment, the World Bank (WB) will issue an annual Doing Business every year. The WB measures the ease of doing business (EDB) based on the whole life cycle of an enterprise, from the initial stage of entrepreneurship to acquisition of a business site, financing, daily operation, and operation in a safe business environment. To measure EDB of each country, the WB measures EDB scores of various indicators every year to calculate the sum based on a simple additive weighting method. In this way, the EDB rankings of 190 countries in the world are determined. Various indicators, based on which the WB calculates EDB ranking, are significantly correlated with one another, and various economies show a great difference in terms of various indicators; however, when calculating EDB ranking, the WB just calculates the gap between each country with the country with the frontier score. Moreover, the WB only performs simple additive weighting for various indicator data but also ignores the dependency of various indicators and the distance of various economies to negative ideal points. Obviously, the method for calculating EDB ranking remains to be modified. How best to evaluate the business environments of BRI countries has attracted attention of many scholars.

As for evaluation objects, existing research mostly only evaluates the business environments of a small number of BRI countries. For example, by investigating the business environment of Nepal, Shrestha (2017) found that although the economic growth potential of Nepal is high, there are a series of problems such as unsound rule of law and imperfect infrastructure. By analysing business environments of the five countries in Central Asia, Yue and Qian (2015) showed that the five countries have a significant difference, however, either at an infrastructural level and in terms of financial environment or in political environment and labour market contexts, Kazakhstan's EDB is optimal; Huang (2019) evaluated the business environments of 64 BRI countries and showed that Singapore, Bhutan, Nepal, Myanmar, Laos, and most countries in Central and Eastern Europe have the best business environment while India's business environment is the worst. Some scholars also explored business environments of a minority of BRI countries (Zhong \& Fan, 2016; Xu et al., 2015; Du \& Zhang, 2018). These scholars carry outed analysis mostly focusing on 64 countries. Among the 64 countries, Singapore and New Zealand exhibit a relatively favourable business environment; by contrast, business environments of Kyrghyzstan, Tajikistan, etc. are relatively poor.

In terms of evaluation method, scholars mostly apply extended gravity models and an analytic hierarchy process (AHP) or evaluate the business environment directly based on the WB's evaluation indicator system. By utilising an extended gravity model, Kong and Dong (2015) validated the promotion effect of trade facilitation on trade between BRI countries is more significant compared with regional economic organisations, national GDP (gross domestic product) brought about by import and export, tariff reduction and exemption, 
etc. Cui and Huang (2016) explored the evaluation indicator system for trade and investment facilitation of BRI countries by employing AHP and further measured the trade and investment facilitation levels of various BRI countries. Additionally, in the literature, business environments in different countries were measured mostly according to EDB rankings or EDB scores issued by the WB (Escaleras \& Chiang, 2017; Lu \& Chen, 2018; Corcoran \& Gillanders, 2015). The WB's evaluation system is relatively comprehensive; however, the calculation method for EDB ranking issued by the WB fails to utilise fully raw data to reflect the gap between various countries on the one hand; on the other hand, the method often leads to the occurrence of problems such as information overlapping.

Above all, the existing research exhibits two drawbacks: firstly, scholars evaluate business environments mostly based on EDB rankings issued by the WB, which often causes information overlapping and insufficient information utilisation. Secondly, some 125 countries are participating in the BRI initiative while only a small number of them were systematically evaluated in the existing literature.

Ranking business environments of BRI countries belongs to a multiple attribute decision-making problem: among numerous methods for multiple attribute decision-making, the technique for order preference by similarity to an ideal solution (TOPSIS) method is widely applied to good effect due to its simple principle, intuitive geometrical significance, and imposing no special requirement on sample data (Dwivedi et al., 2018; Sirisawat \& Kiatcharoenpol, 2018; Vidal \& Sánchez-Pantoja, 2019). Numerous scholars have also improved the traditional TOPSIS method applied the improved method to empirical research. A summary of the literature on improved TOPSIS in recent years is given in Table 1.

By using Mahalanobis distance-based TOPSIS, the method for calculating EDB ranking issued by the WB is modified to solve a series of problems, including high dependency between various indicators and ignoring negative ideal points during calculation. Moreover, the business environments of $121 \mathrm{BRI}$ countries are evaluated and ranked. The innovation in the research is as follows:

1) Based on data concerning all primary indicators in the WB's Doing Business database, the business environments of BRI countries are assessed by using traditional TOPSIS method to calculate the closeness of indicators of various countries. On this basis, all BRI countries are ranked, in expecting to solve the problem of only considering gap of each country to the country with frontier score while ignoring that to the country with the lowest score when calculating EDB scores.

2) By introducing the Mahalanobis distance, the traditional TOPSIS method is improved. According to raw data pertaining to various indicators, the closeness of indicators of various countries is separately calculated by using Mahalanobis distance-based TOPSIS. On this basis, all BRI countries are ranked. Mahalanobis distance considers the relationship between various indicators and is dimensionless. Therefore, it can solve the problem of information overlapping, which is not considered in traditional TOPSIS methods or that used in EDB ranking.

3) All BRI countries are ranked separately according to results of similarity obtained by using the traditional TOPSIS method and Mahalanobis distance-based TOPSIS. Additionally, from the statistical and geographical perspectives, a comparison is made to analyse differences in the ranking results of the two methods with the ranking issued by the WB. 
Table 1. Summary of the literature regarding improved TOPSIS in recent years

\begin{tabular}{|c|c|c|c|}
\hline Author(s) & Improvement(s) & Application(s) & Result(s) \\
\hline $\begin{array}{l}\text { Tang, Shi, } \\
\text { and Dong } \\
\text { (2018) }\end{array}$ & $\begin{array}{l}\text { using entropy and } \\
\text { TOPSIS }\end{array}$ & $\begin{array}{l}\text { public blockchain } \\
\text { evaluation }\end{array}$ & $\begin{array}{l}\text { Bitcoin, Ethereum and EOS are ranked } \\
\text { in the top three public blockchains. }\end{array}$ \\
\hline $\begin{array}{l}\text { Wang and } \\
\text { Wang (2014) }\end{array}$ & $\begin{array}{l}\text { using a TOPSIS } \\
\text { Method Based on } \\
\text { Entropy Weight } \\
\text { and Mahalanobis } \\
\text { Distance }\end{array}$ & $\begin{array}{l}\text { the External } \\
\text { Performance } \\
\text { appraisal of China } \\
\text { Energy } \\
\text { Regulation }\end{array}$ & $\begin{array}{l}\text { Compared to the social responsibility } \\
\text { performance, the fluctuation of external } \\
\text { economic performance more sensitive } \\
\text { to energy regulation. }\end{array}$ \\
\hline $\begin{array}{l}\text { Walczak and } \\
\text { Rutkowska } \\
(2017)\end{array}$ & $\begin{array}{l}\text { use the fuzzy } \\
\text { TOPSIS method }\end{array}$ & $\begin{array}{l}\text { project rankings } \\
\text { for participatory } \\
\text { budget }\end{array}$ & $\begin{array}{l}\text { The paper describes the application of } \\
\text { fuzzy TOPSIS with a modification for } \\
\text { PB. }\end{array}$ \\
\hline Gupta (2018) & $\begin{array}{l}\text { BWM \& fuzzy } \\
\text { TOPSIS }\end{array}$ & \begin{tabular}{|l|} 
evaluating \\
organization \\
performance \\
\end{tabular} & $\begin{array}{l}\text { The paper provides a framework for } \\
\text { managers to evaluate their organization's } \\
\text { performance. }\end{array}$ \\
\hline $\begin{array}{l}\text { Piwowarski, } \\
\text { Miłaszewicz, } \\
\text { Łatuszyńska, } \\
\text { Borawski, } \\
\text { and } \\
\text { Nermend }\end{array}$ & TOPSIS \& VIKOR & $\begin{array}{l}\text { study of sustainable } \\
\text { development in the } \\
\text { EU countries }\end{array}$ & $\begin{array}{l}\text { The paper studies sustainable } \\
\text { development in the EU countries. }\end{array}$ \\
\hline $\begin{array}{l}\text { Sun, Miao, } \\
\text { and Yang } \\
(2018)\end{array}$ & $\begin{array}{l}\text { entropy weighted } \\
\text { TOPSIS }\end{array}$ & $\begin{array}{l}\text { ecological- } \\
\text { economic efficiency } \\
\text { evaluation }\end{array}$ & $\begin{array}{l}\text { The highest is the home audio-visual } \\
\text { equipment manufacturers and the } \\
\text { lowest is the electronic computer } \\
\text { manufacturers. }\end{array}$ \\
\hline $\begin{array}{l}\text { Zeng and } \\
\text { Xiao (2018) }\end{array}$ & $\begin{array}{l}\text { HFOWAWAD- } \\
\text { TOPSIS }\end{array}$ & $\begin{array}{l}\text { energy policy } \\
\text { selection }\end{array}$ & $\begin{array}{l}\text { Reflect the importance of the degrees of } \\
\text { the subjective information of attribute } \\
\text { and the attitudinal character of decision } \\
\text { maker. }\end{array}$ \\
\hline $\begin{array}{l}\text { dos Santos, } \\
\text { Godoy, and } \\
\text { Campos } \\
(2019)\end{array}$ & Entropy-TOPSIS-F & $\begin{array}{l}\text { performance } \\
\text { evaluation of green } \\
\text { suppliers }\end{array}$ & $\begin{array}{l}\text { "Management Commitment to GSCM", } \\
\text { "Ecodesign" and "Environmental } \\
\text { management system" are the first three } \\
\text { criteria in the ranking of selection of } \\
\text { sustainable suppliers. }\end{array}$ \\
\hline $\begin{array}{l}\text { Bai and } \\
\text { Sarkis (2018) }\end{array}$ & Grey-based TOPSIS & $\begin{array}{l}\text { evaluating supplier } \\
\text { performance }\end{array}$ & $\begin{array}{l}\text { The paper provides support for } \\
\text { sustainable supplier selection. }\end{array}$ \\
\hline $\begin{array}{l}\text { Wang, Hao, } \\
\text { Gao, Zhang, } \\
\text { and Zhou } \\
(2019)\end{array}$ & DEA-TOPSIS & $\begin{array}{l}\text { shanghai End- } \\
\text { of-life vehicles } \\
\text { industry }\end{array}$ & $\begin{array}{l}\text { The DEA-TOPSIS method based on } \\
\text { TES is effective for multi-attribute } \\
\text { decision-making to improve the ELV } \\
\text { reverse logistics industry's efficiency. }\end{array}$ \\
\hline $\begin{array}{l}\text { Khan, Bilal, } \\
\text { and Young } \\
\text { (2018) }\end{array}$ & Fuzzy-TOPSIS & $\begin{array}{l}\text { mobile wireless } \\
\text { sensor networks }\end{array}$ & $\begin{array}{l}\text { Results shows that the proposed } \\
\text { scheme improves the network lifetime } \\
\text { by } 60 \% \text {, conserve energy by } 80 \% \text {, } \\
\text { a significant reduction of frequent } \\
\text { Cluster Head }(\mathrm{CH}) \text { per round selection } \\
\text { by } 25 \% \text { is achieved as compared to } \\
\text { the conventional Fuzzy and LEACH } \\
\text { protocols. }\end{array}$ \\
\hline
\end{tabular}


End of Table 1

\begin{tabular}{|c|c|c|c|}
\hline Author(s) & Improvement(s) & Application(s) & Result(s) \\
\hline $\begin{array}{l}\text { Ouenniche, } \\
\text { Pérez- } \\
\text { Gladish, } \\
\text { and Bouslah } \\
\text { (2018) }\end{array}$ & TOPSIS classifiers & $\begin{array}{l}\text { bankruptcy } \\
\text { prediction }\end{array}$ & $\begin{array}{l}\text { Empirical results show an outstanding } \\
\text { predictive performance both in-sample } \\
\text { and out-of-sample and thus opens a new } \\
\text { avenue for research and applications } \\
\text { in risk modelling and analysis using } \\
\text { TOPSIS as a non-parametric classifier } \\
\text { and makes it a real contender in } \\
\text { industry applications in banking and } \\
\text { investment. }\end{array}$ \\
\hline
\end{tabular}

Notes: DEA = Data Envelopment Analysis; VIKOR = VIsekrzterijumska Optimizacija i Kompromisno Resenje; BWM = Best Worst Method; F = Fuzzy; TES = Triple Exponential Smoothing; HFOWAWAD-TOPSIS $=$ Hesitant fuzzy ordered weighted averaging weighted averaging distance (HFOWAWAD) measure, a modified hesitant fuzzy TOPSIS.

The rest of the study is organized as follows: Section 1 introduces evaluation methods, involving traditional TOPSIS method and Mahalanobis distance-based TOPSIS; Section 2 empirically analyses the ranking of business environments of BRI countries and discusses the evaluation result from statistical and geographical perspectives; last Section concludes.

\section{Evaluation methods}

The traditional TOPSIS method inevitably shows the drawback of causing information loss (Wang \& Wang, 2014; Wang et al., 2018) while Mahalanobis distance can favourably solve the problem of linear correlation between indicators (Ke et al., 2018; Hamill et al., 2016; González-Arteaga et al., 2016) and compensate for deficiencies in the traditional TOPSIS method. In the present study, the traditional TOPSIS method and Mahalanobis distancebased TOPSIS are introduced.

\subsection{Traditional TOPSIS method}

TOPSIS is a method for dealing with uncertain multi-attribute decision-making problem, which is applied to conduct ranking based on the distances of an evaluation object to positive and negative ideal solutions (Pelegrina et al., 2019; Zeng et al., 2020b; Yoon \& Kim, 2017). A positive ideal solution consists of optimal values of all indicators while the negative ideal solution comprises the worst values of all indicators (Zeng et al., 2020a; Jiang et al., 2019; Zareie et al., 2018).

It is supposed that there are $m$ countries $A=\left\{A_{1}, A_{2}, \ldots, A_{m}\right\}$ and $n$ indicators $F=\left\{f_{1}, f_{2}, \ldots, f_{n}\right\}$. The decision matrix $X=\left(x_{i j}\right)_{m \times n}, i=1,2, \ldots, m ; j=1,2, \ldots, n$ for decision making is established, in which $x_{i j}$ denotes the value of $j$ th indicator of the $i$ th country. The specific steps of TOPSIS method for evaluation are summarised as follows (Yoon, 1987; Hwang et al., 1993; Hwang \& Yoon, 1981):

Normalised decision matrix $R=\left(r_{i j}\right)_{m \times n}$ is constructed, that is, the decision matrix is normalised, where,

$$
r_{i j}=\frac{x_{i j}}{\sqrt{\sum_{i=1}^{m} x_{i j}^{2}}} .
$$


Afterwards, positive and negative ideal solutions $S^{+}$and $S^{-}$are determined:

$$
\begin{aligned}
& S^{+}=\left\{s_{1}^{+}, s_{2}^{+}, \cdots, s_{n}^{+}\right\} ; \\
& S^{-}=\left\{s_{1}^{-}, s_{2}^{-}, \cdots, s_{n}^{-}\right\}, \\
& s_{j}^{+}=\max _{i}, j=1,2, \cdots, n . s_{j}^{-}=\operatorname{minr}_{i}, j=1,2, \cdots, n .
\end{aligned}
$$

Next, Euclidean distances $\left(d_{i}^{+}\right.$and $d_{i}^{-}$) of indicators of various countries to positive and negative ideal solutions are separately calculated:

$$
\begin{aligned}
& d_{i}^{+}=\sqrt{\sum_{j=1}^{n}\left(s_{j}^{+}-r_{i j}\right)^{2}}, i=1,2, \ldots, m ; \\
& d_{i}^{-}=\sqrt{\sum_{j=1}^{n}\left(s_{j}^{-}-r_{i j}\right)^{2}}, i=1,2, \ldots, m .
\end{aligned}
$$

Subsequently, the relative closeness $c_{i}$ of indicators of various countries to positive ideal solution is separately calculated:

$$
c_{i}=\frac{d_{i}^{-}}{d_{i}^{-}+d_{i}^{+}}, i=1,2, \ldots, m .
$$

Finally, according to the level of $c_{i}$, ranking is carried out: the larger $c_{i}$ is, the better the scheme.

Traditional TOPSIS evaluation objectively reflects the gap between various countries by introducing positive and negative ideal solutions; however, when there is a significant linear relationship between indicators, column vector consisting of $n$ different attribute indicators fails to make up a group of bases for measuring the linear space. Therefore, in this case, calculating the distances of indicators of various countries to positive and negative ideal solutions according to Euclidean distance will lead to erroneous final rankings for various countries.

\subsection{Mahalanobis distance-based TOPSIS}

To tackle the problem of information overlapping caused by dependency between variables, Mahalanobis distance is introduced to improve the traditional TOPSIS method (Antuchevičienė et al., 2010; Chang et al., 2010). As a statistical distance, Mahalanobis distance is independent of measurement scale and is unaffected by dimension of coordinates. Moreover, it can eliminate interference caused by dependency between variables (that is, removing the influence induced by linear correlation between attribute indicators).

It is assumed that there are $m$ countries $A=\left\{A_{1}, A_{2}, \ldots, A_{m}\right\}$ and $n$ indicators $F=\left\{f_{1}, f_{2}, \ldots, f_{n}\right\}$. The decision matrix $X=\left(x_{i j}\right)_{m \times n}, i=1,2, \ldots, m ; j=1,2, \ldots, n$ for decision making is established, in which $x_{i j}$ denotes the value of $j$ th indicator of the $i$ th country. $x_{i}$ refers to the spatial coordinates of the corresponding attribute value of the $i$ th country. The specific steps of the Mahalanobis distance-based TOPSIS for evaluation are described below. 
Positive and negative ideal solutions $S^{+}$and $S^{-}$are determined;

$S^{+}=\left\{s_{1}^{+}, s_{2}^{+}, \cdots, s_{n}^{+}\right\}$and $S^{-}=\left\{s_{1}^{-}, s_{2}^{-}, \cdots, s_{n}^{-}\right\}$represent corresponding spatial coordinates of positive and negative ideal solutions, where, $s_{j}^{+}=\max _{i} x_{i j}, j=1,2, \cdots, n \cdot s_{j}^{-}=\min _{i} x_{i j}, j=1,2, \cdots, n$.

Next, Mahalanobis distances ( mahal $_{i}^{+}$and mahal $_{i}^{-}$) of indicators of various countries to positive and negative ideal solutions are separately calculated:

$$
\begin{aligned}
& \operatorname{mahal}\left(x_{i}, S^{+}\right)=\sqrt{\left\{x_{i j}-s_{j}^{+}\right\}^{T} \Sigma^{-1}\left\{x_{i j}-s_{j}^{+}\right\}}, i=1,2, \ldots, m ; \\
& \operatorname{mahal}\left(x_{i}, S^{,-}\right)=\sqrt{\left\{x_{i j}-s_{j}^{{ }^{-}}\right\}^{T} \Sigma^{-1}\left\{x_{i j}-s_{j}{ }^{-}\right\}}, i=1,2, \ldots, m,
\end{aligned}
$$

where, $\Sigma^{-1}$ denotes the inverse matrix of covariance matrix $\Sigma$ of $n$ attribute variables $x_{1}, x_{2}, \cdots, x_{n}$.

Subsequently, the relative closeness $c_{i}$ of indicators of various countries to positive ideal solution is separately calculated:

$$
c_{i}=\frac{\operatorname{mahal}\left(x_{i}, S^{-}\right)}{\operatorname{mahal}\left(x_{i}, S^{-}\right)+\operatorname{mahal}\left(x_{i}, S^{+}\right)}, i=1,2, \ldots, m .
$$

Finally, ranking is conducted according to the level of $c_{i}$. The larger $c_{i}$, the better the scheme.

When evaluation indicators are significantly correlated, Mahalanobis distance is unaffected by dimension of indicators and also eliminates the information overlapping caused by linear correlation of indicators. Therefore, Mahalanobis distance is more applicable for dealing with complex practical problems. Additionally, in practical application, the overall covariance matrix is generally unknown so can be replaced with a sample covariance matrix.

\section{Empirical analysis of the business environments of BRI countries}

Based on indicator data for business environments of various countries issued by the WB, 121 BRI countries are ranked by separately using a traditional TOPSIS method and Mahalanobis distance-based TOPSIS. Moreover, the list of $121 \mathrm{BRI}$ countries was copied from the Belt and Road Portal (n.d.). The EDB rankings and indicator data for business environments of various BRI countries are all taken from Doing Business 2019: Training for Reform (The World Bank, 2018). The organisation of empirical analysis is described below.

At first, the indicator system for empirical analysis is explained and indicator data are subjected to descriptive statistical analysis. The mode and median of indicator data are separately calculated and Pearson correlation analysis is undertaken.

Afterwards, based on various indicator data, the WB's rankings are collected and recorded. By separately utilising the traditional TOPSIS method and Mahalanobis distance-based TOPSIS introduced in the last section, the EDB of various BRI countries is ranked.

Finally, statistical analysis is carried out on empirical results. The BRI countries are divided into nine regions including Northeast Asia and Southeast Asia according to their geographical locations. The results obtained through empirical analysis and statistical analysis are mapped. 


\subsection{Indicator system and data analysis}

\subsubsection{Indicator system}

The WB's Doing Business database has a set of mature and stable indicator system, which is used for measuring and evaluating EDB of various countries. Since 2003, the WB has issued Doing Business report every year. The report measures the supervision and regulations of each country (region) for their medium and small-sized enterprises based on ten indicator sets. The measurement indicators cover ten fields of life cycle of an enterprise, which can be partitioned into two aspects. The two aspects are respectively used to measure the effectiveness of government supervision on enterprises and completeness of the legal system of various countries. The former is applied to measure supervisory process and efficiency involved in starting a business, applying for construction permits, getting electricity, registering property, paying taxes and trading across borders; the latter is employed to evaluate the soundness of law and regulation framework in various aspects, including getting credit, protecting minority investors, enforcing contracts and resolving insolvency. These indicators are used to evaluate procedure, time and cost for completing a deal according to related regulations from the perspectives of enterprises, which are sound and perfect. Economic literature is used to validate the economic relevance and importance of the fields in which business environment is measured. By taking starting a business as an example, since 2003, 100 top-level academic journals have published more than 300 research papers describing how to evaluate how the regulation environment for market access influences extensive economic results such as production efficiency, growth, employment and informality (The World Bank, 2018). By taking the indicator system as reference standard, analysis is conducted (Table 2).

Table 2. Indicator system for business environment (source: The World Bank, 2018)

\begin{tabular}{|c|l|}
\hline Indicator set & \multicolumn{1}{c|}{ Measurement content } \\
\hline $\begin{array}{c}\text { Starting a business } \\
\left(X_{1}\right)\end{array}$ & $\begin{array}{l}\text { Procedures, time, cost and minimum contributed capital required when a male } \\
\text { or a female starts a limited liability company. }\end{array}$ \\
\hline $\begin{array}{c}\text { Applying for } \\
\text { construction } \\
\text { permits }\left(X_{2}\right)\end{array}$ & $\begin{array}{l}\text { All procedures, time, cost of building warehouse and quality control and safety } \\
\text { mechanism in construction permit system. }\end{array}$ \\
\hline $\begin{array}{c}\text { Getting } \\
\text { electricity }\left(X_{3}\right)\end{array}$ & $\begin{array}{l}\text { Procedures, time and cost of connecting to the power grid, reliability of power } \\
\text { supply, and transparency of electric charge. }\end{array}$ \\
\hline $\begin{array}{c}\text { Registering } \\
\text { property }\left(X_{4}\right)\end{array}$ & $\begin{array}{l}\text { Procedures, time and cost of dealing with land transfer and quality of land } \\
\text { administration by a male or a female. }\end{array}$ \\
\hline Getting credit $\left(X_{5}\right)$ & law of chattel mortgage and credit information system. \\
\hline $\begin{array}{c}\text { Protecting minority } \\
\text { investors }\left(X_{6}\right)\end{array}$ & Minority shareholders' rights in related transaction and corporate governance. \\
\hline $\begin{array}{c}\text { Paying taxes } \\
\left(X_{7}\right)\end{array}$ & $\begin{array}{l}\text { The number and time of tax payments, total tax, total amount of levies, and } \\
\text { post-filing process during the operation of a company complying with all tax } \\
\text { laws and regulations. }\end{array}$ \\
\hline $\begin{array}{c}\text { Trading across } \\
\text { borders }\left(X_{8}\right)\end{array}$ & $\begin{array}{l}\text { Time and cost of exporting relatively superior products and importing auto } \\
\text { parts. }\end{array}$ \\
\hline $\begin{array}{c}\text { Enforcing contracts } \\
\left(X_{9}\right)\end{array}$ & $\begin{array}{l}\text { Time and cost of solving commercial dispute and quality when a male or a } \\
\text { female performs judicial process. }\end{array}$ \\
\hline $\begin{array}{c}\text { Resolving } \\
\text { insolvency }\left(X_{10}\right)\end{array}$ & $\begin{array}{l}\text { Time, cost, result and recovery rate of insolvency and intensity of insolvency } \\
\text { legal framework. }\end{array}$ \\
\hline
\end{tabular}




\subsubsection{Descriptive statistical analysis}

Various characteristics (including high dependency) of various indicator data are likely to affect empirical result. To understand the characteristics (such as discrete degree, distribution condition and dependency) of various indicator data, all indicator data are subjected to descriptive statistical analysis before further empirical analysis. The specific descriptive statistical results are shown in Table 3: the maxima and minima of all indicators are all within reasonable ranges and the mean of various indicators is much greater than their standard deviation. This indicates that the discreteness of the data is low and the probability of having extreme outliers is low. The mean, median, and mode of starting a business $\left(X_{1}\right)$ are relatively approximated to those of enforcing contracts $\left(X_{9}\right)$, implying that the data of the two indicators are approximately symmetrically distributed. According to value of skewness, it can be seen that the 10 indicator data values all exhibit a right-skewed distribution.

Furthermore, Pearson correlation analysis is conducted on all indicator data to test the correlation between indicators. The results of correlation analysis are shown in Table 4 . There

Table 3. Descriptive statistics

\begin{tabular}{|l|c|c|c|c|c|c|c|c|}
\hline & Mode & Median & Mean & $\begin{array}{c}\text { Standard } \\
\text { Deviation }\end{array}$ & Maximum & Minimum & Kurtosis & Skewness \\
\hline$X_{1}$ & 83.900 & 85.070 & 82.976 & 12.144 & 99.980 & 25.000 & 7.064 & -1.709 \\
\hline$X_{2}$ & 0.000 & 67.640 & 64.489 & 15.733 & 86.960 & 0.000 & 10.084 & -2.252 \\
\hline$X_{3}$ & 0.000 & 71.410 & 67.137 & 20.834 & 100.000 & 0.000 & 4.249 & -1.069 \\
\hline$X_{4}$ & 50.140 & 63.670 & 62.324 & 17.604 & 94.890 & 0.000 & 4.183 & -0.571 \\
\hline$X_{5}$ & 70.000 & 55.000 & 52.314 & 24.758 & 100.000 & 0.000 & 2.278 & -0.308 \\
\hline$X_{6}$ & 51.670 & 55.000 & 55.124 & 15.498 & 85.000 & 0.000 & 3.195 & -0.320 \\
\hline$X_{7}$ & 84.720 & 71.480 & 67.706 & 17.405 & 99.440 & 0.000 & 4.859 & -1.081 \\
\hline$X_{8}$ & 100.000 & 70.360 & 68.167 & 22.671 & 100.000 & 0.000 & 3.109 & -0.689 \\
\hline$X_{9}$ & 59.330 & 56.440 & 55.926 & 13.510 & 84.530 & 6.130 & 3.011 & -0.582 \\
\hline$X_{10}$ & 0.000 & 42.420 & 42.392 & 20.925 & 83.660 & 0.000 & 2.876 & -0.422 \\
\hline
\end{tabular}

Table 4. Pearson correlation

\begin{tabular}{|c|c|c|c|c|c|c|c|c|c|c|}
\hline & $X_{1}$ & $X_{2}$ & $X_{3}$ & $X_{4}$ & $X_{5}$ & $X_{6}$ & $X_{7}$ & $X_{8}$ & $X_{9}$ & $X_{10}$ \\
\hline$X_{1}$ & 1.000 & $409^{\star *}$ & $494^{\star \star}$ & $386^{\star *}$ & $386^{* *}$ & $604^{\star *}$ & $.544^{\star *}$ & $.420^{\star *}$ & $.367^{\star *}$ & $0.374^{\star *}$ \\
\hline$X_{2}$ & $409^{\star *}$ & 000 & $592^{* \star}$ & $490^{\star *}$ & $0.436^{\star *}$ & $0.443^{\star *}$ & $0.394^{* *}$ & $0.431^{* *}$ & $0.363^{* *}$ & $0.370^{\star *}$ \\
\hline$X_{3}$ & $9 y^{* *}$ & $92^{\star *}$ & 000 & $483^{\star *}$ & $474^{* *}$ & $488^{\star *}$ & $0.529^{\star *}$ & $0.595^{\star *}$ & $0.426^{* *}$ & $.502^{\star \star}$ \\
\hline$X_{4}$ & $0.386^{\prime}$ & $0.490^{\star *}$ & $0.483^{x}$ & 1.00 & $*$ & $*$ & $+*$ & 0.5 & $* *$ & $71^{\star *}$ \\
\hline$X_{5}$ & $0.386^{* *}$ & $0.436^{* *}$ & $0.474^{* *}$ & $0.504^{* *}$ & 1.000 & $0.581^{* *}$ & $0.360^{* *}$ & $0.483^{* *}$ & $0.443^{* *}$ & $0.521^{\star *}$ \\
\hline$X_{6}$ & $0.604^{* *}$ & $0.443^{* *}$ & $0.488^{\star *}$ & $0.440^{* \star}$ & $0.581^{\star *}$ & 1.000 & $0.506^{* *}$ & $0.420^{* *}$ & $0.390^{* *}$ & $0.593^{* *}$ \\
\hline$X_{7}$ & $0.544^{\star *}$ & $0.394^{\star *}$ & $0.529^{\star *}$ & $0.540^{\star \star}$ & $0.360^{\star *}$ & $0.506^{\star *}$ & 1.000 & $0.522^{\star *}$ & $0.478^{\star \star}$ & $0.351^{\star *}$ \\
\hline$X_{8}$ & $0.420^{* *}$ & $0.431^{* *}$ & $0.595^{\star *}$ & $0.570^{* *}$ & $0.483^{* *}$ & $0.420^{* *}$ & $0.522^{\star *}$ & 1.000 & $0.491^{* *}$ & $0.511^{* *}$ \\
\hline$X_{9}$ & $0.367^{\star *}$ & $0.363^{\star *}$ & $0.426^{\star *}$ & $0.679 * *$ & $0.443^{\star *}$ & $0.390^{\star *}$ & $0.478^{\star *}$ & $0.491^{* *}$ & 1.000 & $0.406^{\star *}$ \\
\hline$X_{10}$ & $374^{\star \star}$ & $0.370^{\star \star}$ & $0.502^{\star \star}$ & $0.471^{\star *}$ & $0.521^{\star \star}$ & $0.593^{\star \star}$ & $0.351^{\star *}$ & $0.511^{\star *}$ & $0.406^{\star *}$ & 1.000 \\
\hline
\end{tabular}

Note: ${ }^{* *}$ exhibits a significant correlation under a level of 0.01 (bilateral). 
is a common correlation between various indicators and the correlation coefficient is statistically significant at the significance level of $1 \%$. Therefore, when selecting indicator evaluation method, it is essential to select a proper method to deal with the correlation of various indicators to eliminate repetitive computation of information.

\subsection{Empirical results}

The empirical results are organised as follows: at first, by looking up rankings of business environments of 190 countries across the world issued by the WB, rankings of business environments of $121 \mathrm{BRI}$ countries are attained; then, using a traditional TOPSIS method, the rankings of business environments of BRI countries are calculated; Finally, the business environments of BRI countries are ranked by applying Mahalanobis distance-based TOPSIS.

\subsubsection{Ranking method 1 : collecting ranking results issued by the WB}

Doing Business issued by the WB synthesised 10 indicators to list two criteria for measuring business environments of various countries (regions): EDB score and EDB ranking. The latter is sorted according to the level of the former: the country (region) with a higher EDB score ranks higher and vice versa. The EDB score is calculated by using simple additive weighting after assigning each indicator the same weight.

By looking up Doing Business 2019: Training for Reform issued by the WB, the EDB scores of $121 \mathrm{BRI}$ countries are collected. According to scores, the BRI countries are ranked and the result is shown in Table 5.

\subsubsection{Ranking method 2: traditional TOPSIS method}

Based on the design of traditional TOPSIS method for business environments of BRI countries and construction and selection of the aforementioned evaluation indicators, the business environments of $121 \mathrm{BRI}$ countries are ranked. The specific calculation steps are described below.

At first, by using all indicator data of 121 BRI countries, a $121 \times 10$ decision matrix for decision making is established. Where, $x_{i j}$ refers to the value of the $j$ th indicator of the $i$ th BRI country. The decision matrix for decision making is normalised based on (1).

Afterwards, the maximum of each column in the normalised decision matrix for decision making is collected to construct the positive ideal solutions $S^{+}$of various indicators. Similarly, the minimum of each column is used to establish the negative ideal solutions $S^{-}$of various indicators. The results are described below.

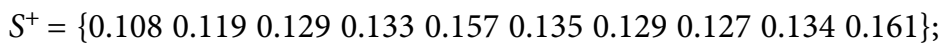

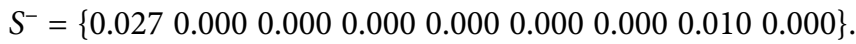

Subsequently, according to Eqs (4) and (5), by applying the positive and negative ideal solutions obtained in the last step and the normalised decision matrix for decision making, the Euclidean distances $\left(d_{i}^{+}\right.$and $\left.d_{i}^{-}\right)$of indicators of different countries to positive and negative ideal solutions are calculated. 
Finally, according to Equation (6), the relative closeness $c_{i}$ of indicators of BRI countries to positive ideal solution is separately calculated using $d_{i}^{+}$and $d_{i}^{-}$. Where, the larger the closeness $c_{i}$, the closer the indicators of a country to the positive ideal solution and the higher the EDB ranking of the country. The specific ranking result is displayed in Table 5.

\subsubsection{Ranking method 3: Mahalanobis distance-based TOPSIS}

According to the indicator system aforementioned and indicator data of the WB's Doing Business database, the business environments of BRI countries are evaluated by employing Mahalanobis distance-based TOPSIS. The specific steps for evaluation are as follows:

At first, using all indicator data of $121 \mathrm{BRI}$ countries, a $121 \times 10$ decision matrix is established in which, $x_{i j}$ denotes the value of the $j$ th indicator of the $i$ th BRI country.

Afterwards, the maximum of each column in the decision matrix is calculated to build the positive ideal solutions $S^{+}$of various indicators. Here:

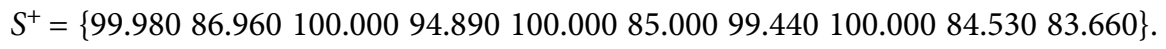

The minimum of each column in the decision matrix is derived to determine the negative ideal solutions $S^{-}$of various indicators. Here:

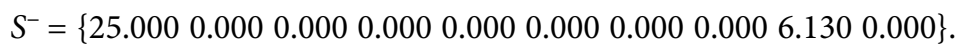

Subsequently, the covariance matrix $\Sigma$ of the decision matrix is calculated to attain its inverse matrix $\Sigma^{-1}$ through inverse calculation. Based on Eqs (7) and (8), Mahalanobis distances mahal $_{i}^{+}$and mahal $_{i}^{-}$of indicators of various BRI countries to positive and negative ideal solutions are calculated using the decision matrix and the attained $\Sigma^{-1}, S^{+}$and $S^{-}$.

Finally, according to Eq. (9), based on mahal $_{i}^{+}$and mahal $_{i}^{-}$found above, the closeness $c_{i}$ of indicators of various BRI countries to the positive ideal solution is separately calculated. The larger the closeness $c_{i}$, the better the business environment of a country and the higher the EDB ranking thereof. The specific $c_{i}$ values and ranking result are listed in Table 5.

Table 5. The EDB ranking results of WB \& traditional TOPSIS method \& Mahalanobis distance-based

\begin{tabular}{|c|c|c|c|c|c|c|}
\hline \multirow[t]{2}{*}{ Country } & \multicolumn{2}{|c|}{$\begin{array}{c}\text { The EDB ranking results } \\
\text { of } \mathrm{WB}\end{array}$} & \multicolumn{2}{|c|}{$\begin{array}{l}\text { The EDB ranking results of } \\
\text { traditional TOPSIS method }\end{array}$} & \multicolumn{2}{|c|}{$\begin{array}{c}\text { The EDB ranking results } \\
\text { of Mahalanobis distance-based } \\
\text { TOPSIS }\end{array}$} \\
\hline & $\begin{array}{l}\text { EDB } \\
\text { score }\end{array}$ & $\begin{array}{l}\text { EDB ranking } \\
\text { results }\end{array}$ & closeness & $\begin{array}{l}\text { EDB ranking } \\
\quad \text { results }\end{array}$ & closeness & EDB ranking results \\
\hline New Zealand & 86.590 & 1 & 0.894 & 1 & 0.813 & 2 \\
\hline Singapore & 85.240 & 2 & 0.875 & 2 & 0.847 & 1 \\
\hline Korea & 84.140 & 3 & 0.843 & 4 & 0.775 & 7 \\
\hline Georgia & 83.280 & 4 & 0.839 & 5 & 0.797 & 4 \\
\hline $\begin{array}{l}\text { Republic of } \\
\text { Macedonia }\end{array}$ & 81.550 & 5 & 0.850 & 3 & 0.800 & 3 \\
\hline $\begin{array}{l}\text { United Arab } \\
\text { Emirates }\end{array}$ & 81.280 & 6 & 0.789 & 15 & 0.757 & 10 \\
\hline Lithuania & 80.830 & 7 & 0.784 & 17 & 0.764 & 8 \\
\hline Malaysia & 80.600 & 8 & 0.826 & 6 & 0.724 & 17 \\
\hline
\end{tabular}
TOPSIS 
Continue of Table 5

\begin{tabular}{|c|c|c|c|c|c|c|}
\hline \multirow{2}{*}{ Country } & \multicolumn{2}{|c|}{$\begin{array}{c}\text { The EDB ranking results } \\
\text { of } \mathrm{WB}\end{array}$} & \multicolumn{2}{|c|}{$\begin{array}{l}\text { The EDB ranking results of } \\
\text { traditional TOPSIS method }\end{array}$} & \multicolumn{2}{|c|}{$\begin{array}{c}\text { The EDB ranking results } \\
\text { of Mahalanobis distance-based } \\
\text { TOPSIS }\end{array}$} \\
\hline & $\begin{array}{l}\text { EDB } \\
\text { score }\end{array}$ & $\begin{array}{l}\text { EDB ranking } \\
\text { results }\end{array}$ & closeness & $\begin{array}{l}\text { EDB ranking } \\
\text { results }\end{array}$ & closeness & EDB ranking results \\
\hline Estonia & 80.500 & 9 & 0.802 & 10 & 0.754 & 12 \\
\hline Latvia & 79.590 & 10 & 0.814 & 7 & 0.788 & 6 \\
\hline Azerbaijan & 78.640 & 11 & 0.812 & 8 & 0.790 & 5 \\
\hline Austria & 78.570 & 12 & 0.791 & 14 & 0.737 & 15 \\
\hline Thailand & 78.450 & 13 & 0.807 & 9 & 0.756 & 11 \\
\hline Kazakhstan & 77.890 & 14 & 0.793 & 13 & 0.760 & 9 \\
\hline Rwanda & 77.880 & 15 & 0.793 & 12 & 0.686 & 28 \\
\hline Russia & 77.370 & 16 & 0.788 & 16 & 0.744 & 14 \\
\hline Poland & 76.950 & 17 & 0.796 & 11 & 0.722 & 18 \\
\hline Czech Republic & 76.100 & 18 & 0.771 & 18 & 0.628 & 57 \\
\hline Belarus & 75.770 & 19 & 0.740 & 23 & 0.685 & 29 \\
\hline Slovenia & 75.610 & 20 & 0.740 & 24 & 0.659 & 45 \\
\hline Armenia & 75.370 & 21 & 0.741 & 22 & 0.700 & 23 \\
\hline Slovakia & 75.170 & 22 & 0.763 & 19 & 0.665 & 44 \\
\hline Turkey & 74.330 & 23 & 0.737 & 26 & 0.719 & 20 \\
\hline China & 73.640 & 24 & 0.736 & 28 & 0.702 & 22 \\
\hline Moldova & 73.540 & 25 & 0.739 & 25 & 0.675 & 36 \\
\hline Serbia & 73.490 & 26 & 0.736 & 27 & 0.696 & 24 \\
\hline Israel & 73.230 & 27 & 0.751 & 21 & 0.728 & 16 \\
\hline Montenegro & 72.730 & 28 & 0.752 & 20 & 0.708 & 21 \\
\hline Romania & 72.300 & 29 & 0.736 & 29 & 0.681 & 33 \\
\hline Hungary & 72.280 & 30 & 0.726 & 30 & 0.685 & 32 \\
\hline Brunei & 72.030 & 31 & 0.723 & 33 & 0.671 & 39 \\
\hline Chile & 71.810 & 32 & 0.723 & 32 & 0.747 & 13 \\
\hline Croatia & 71.400 & 33 & 0.716 & 35 & 0.666 & 43 \\
\hline Bulgaria & 71.240 & 34 & 0.719 & 34 & 0.685 & 31 \\
\hline Morocco & 71.020 & 35 & 0.694 & 38 & 0.721 & 19 \\
\hline Kenya & 70.310 & 36 & 0.724 & 31 & 0.675 & 37 \\
\hline Bahrain & 69.850 & 37 & 0.676 & 39 & 0.669 & 40 \\
\hline Albania & 69.510 & 38 & 0.708 & 36 & 0.646 & 48 \\
\hline Costa Rica & 68.890 & 39 & 0.675 & 41 & 0.624 & 60 \\
\hline Vietnam & 68.360 & 40 & 0.671 & 42 & 0.668 & 41 \\
\hline Kyrgyz Republic & 68.330 & 41 & 0.676 & 40 & 0.610 & 70 \\
\hline Ukraine & 68.250 & 42 & 0.666 & 46 & 0.694 & 25 \\
\hline Greece & 68.080 & 43 & 0.667 & 45 & 0.651 & 46 \\
\hline Indonesia & 67.960 & 44 & 0.700 & 37 & 0.641 & 51 \\
\hline Mongolia & 67.740 & 45 & 0.662 & 48 & 0.680 & 34 \\
\hline Uzbekistan & 67.400 & 46 & 0.671 & 44 & 0.688 & 27 \\
\hline India & 67.230 & 47 & 0.660 & 50 & 0.587 & 83 \\
\hline Oman & 67.190 & 48 & 0.639 & 54 & 0.674 & 38 \\
\hline Panama & 66.120 & 49 & 0.647 & 52 & 0.580 & 89 \\
\hline Tunisia & 66.110 & 50 & 0.660 & 49 & 0.685 & 30 \\
\hline
\end{tabular}


Continue of Table 5

\begin{tabular}{|c|c|c|c|c|c|c|}
\hline \multirow[t]{2}{*}{ Country } & \multicolumn{2}{|c|}{$\begin{array}{c}\text { The EDB ranking results } \\
\text { of } \mathrm{WB}\end{array}$} & \multicolumn{2}{|c|}{$\begin{array}{l}\text { The EDB ranking results of } \\
\text { traditional TOPSIS method }\end{array}$} & \multicolumn{2}{|c|}{$\begin{array}{c}\text { The EDB ranking results } \\
\text { of Mahalanobis distance-based } \\
\text { TOPSIS }\end{array}$} \\
\hline & $\begin{array}{l}\text { EDB } \\
\text { score }\end{array}$ & $\begin{array}{l}\text { EDB ranking } \\
\text { results }\end{array}$ & closeness & $\begin{array}{l}\text { EDB ranking } \\
\text { results }\end{array}$ & closeness & EDB ranking results \\
\hline Bhutan & 66.080 & 51 & 0.595 & 66 & 0.622 & 62 \\
\hline South Africa & 66.030 & 52 & 0.671 & 43 & 0.690 & 26 \\
\hline Qatar & 65.890 & 53 & 0.617 & 57 & 0.604 & 71 \\
\hline Malta & 65.430 & 54 & 0.626 & 56 & 0.647 & 47 \\
\hline Salvador & 65.410 & 55 & 0.652 & 51 & 0.686 & 84 \\
\hline Zambia & 65.080 & 56 & 0.645 & 53 & 0.611 & 69 \\
\hline Bosnia & 63.820 & 57 & 0.662 & 47 & 0.562 & 98 \\
\hline Samoa & 63.770 & 58 & 0.616 & 58 & 0.680 & 35 \\
\hline Saudi Arabia & 63.500 & 59 & 0.584 & 70 & 0.592 & 80 \\
\hline Uruguay & 62.600 & 60 & 0.627 & 55 & 0.628 & 56 \\
\hline $\begin{array}{l}\text { Republic of } \\
\text { Seychelles }\end{array}$ & 62.410 & 61 & 0.615 & 59 & 0.640 & 52 \\
\hline Kuwait & 62.200 & 62 & 0.605 & 61 & 0.666 & 42 \\
\hline Djibouti & 62.020 & 63 & 0.610 & 60 & 0.623 & 61 \\
\hline Sri Lanka & 61.220 & 64 & 0.598 & 64 & 0.615 & 65 \\
\hline $\begin{array}{l}\text { Dominican } \\
\text { Republic }\end{array}$ & 61.120 & 65 & 0.596 & 65 & 0.611 & 67 \\
\hline Dominia & 61.070 & 66 & 0.581 & 72 & 0.642 & 50 \\
\hline Jordan & 60.980 & 67 & 0.582 & 71 & 0.626 & 59 \\
\hline $\begin{array}{l}\text { Trinidad and } \\
\text { Tobago }\end{array}$ & 60.810 & 68 & 0.604 & 62 & 0.576 & 91 \\
\hline Namibia & 60.530 & 69 & 0.601 & 63 & 0.611 & 68 \\
\hline $\begin{array}{l}\text { Papua New } \\
\text { Guinea }\end{array}$ & 60.120 & 70 & 0.591 & 68 & 0.576 & 92 \\
\hline Nepal & 59.630 & 71 & 0.594 & 67 & 0.597 & 76 \\
\hline $\begin{array}{l}\text { Antigua and } \\
\text { Barbuda }\end{array}$ & 59.480 & 72 & 0.572 & 75 & 0.635 & 55 \\
\hline Ghana & 59.220 & 73 & 0.576 & 74 & 0.643 & 49 \\
\hline Palestine & 59.110 & 74 & 0.555 & 81 & 0.536 & 104 \\
\hline $\begin{array}{l}\text { Arab republic of } \\
\text { egypt }\end{array}$ & 58.560 & 75 & 0.584 & 69 & 0.611 & 66 \\
\hline Cote d'Ivoire & 58.000 & 76 & 0.579 & 73 & 0.598 & 74 \\
\hline Philippines & 57.680 & 77 & 0.554 & 82 & 0.571 & 96 \\
\hline Tajikistan & 57.110 & 78 & 0.556 & 80 & 0.640 & 53 \\
\hline Uganda & 57.060 & 79 & 0.571 & 76 & 0.620 & 64 \\
\hline $\begin{array}{l}\text { Islamic Republic } \\
\text { of Iran }\end{array}$ & 56.980 & 80 & 0.560 & 78 & 0.596 & 77 \\
\hline Cape Verde & 55.950 & 81 & 0.520 & 91 & 0.621 & 63 \\
\hline Guyana & 55.570 & 82 & 0.540 & 84 & 0.638 & 54 \\
\hline Mozambique & 55.530 & 83 & 0.541 & 83 & 0.560 & 99 \\
\hline Pakistan & 55.310 & 84 & 0.559 & 79 & 0.581 & 88 \\
\hline Togo & 55.200 & 85 & 0.537 & 86 & 0.590 & 81 \\
\hline Cambodia & 54.800 & 86 & 0.561 & 77 & 0.451 & 119 \\
\hline
\end{tabular}


End of Table 5

\begin{tabular}{|c|c|c|c|c|c|c|}
\hline \multirow{2}{*}{ Country } & \multicolumn{2}{|c|}{$\begin{array}{c}\text { The EDB ranking results } \\
\text { of } \mathrm{WB}\end{array}$} & \multicolumn{2}{|c|}{$\begin{array}{l}\text { The EDB ranking results of } \\
\text { traditional TOPSIS method }\end{array}$} & \multicolumn{2}{|c|}{$\begin{array}{c}\text { The EDB ranking results } \\
\text { of Mahalanobis distance-based } \\
\text { TOPSIS }\end{array}$} \\
\hline & $\begin{array}{l}\text { EDB } \\
\text { score }\end{array}$ & $\begin{array}{l}\text { EDB ranking } \\
\text { results }\end{array}$ & closeness & $\begin{array}{l}\text { EDB ranking } \\
\text { results }\end{array}$ & closeness & EDB ranking results \\
\hline Maldives & 54.430 & 87 & 0.524 & 90 & 0.626 & 58 \\
\hline Senegal & 54.150 & 88 & 0.526 & 88 & 0.593 & 79 \\
\hline Lebanon & 54.040 & 89 & 0.524 & 89 & 0.603 & 63 \\
\hline Tanzania & 53.630 & 90 & 0.538 & 85 & 0.575 & 93 \\
\hline Nigeria & 52.890 & 91 & 0.530 & 87 & 0.586 & 85 \\
\hline Grenada & 52.710 & 92 & 0.493 & 96 & 0.595 & 78 \\
\hline Mauritania & 51.990 & 93 & 0.489 & 97 & 0.589 & 82 \\
\hline Gambia & 51.720 & 94 & 0.505 & 92 & 0.582 & 87 \\
\hline Guinea & 51.510 & 95 & 0.501 & 93 & 0.598 & 75 \\
\hline Laos & 51.260 & 96 & 0.489 & 98 & 0.515 & 111 \\
\hline Zimbabwe & 50.440 & 97 & 0.497 & 95 & 0.527 & 108 \\
\hline Bolivia & 50.320 & 98 & 0.497 & 94 & 0.513 & 112 \\
\hline Algeria & 49.650 & 99 & 0.468 & 102 & 0.523 & 110 \\
\hline Ethiopia & 49.060 & 100 & 0.473 & 105 & 0.583 & 86 \\
\hline Madagascar & 48.890 & 101 & 0.477 & 101 & 0.572 & 95 \\
\hline Sudan & 48.840 & 102 & 0.479 & 100 & 0.570 & 97 \\
\hline Sierra Leone & 48.740 & 103 & 0.472 & 104 & 0.603 & 72 \\
\hline Suriname & 48.050 & 104 & 0.463 & 106 & 0.505 & 113 \\
\hline Cameroon & 47.780 & 105 & 0.472 & 103 & 0.550 & 101 \\
\hline Afghanistan & 47.770 & 106 & 0.482 & 99 & 0.534 & 105 \\
\hline Burundi & 47.410 & 107 & 0.457 & 107 & 0.579 & 90 \\
\hline Gabon & 45.580 & 108 & 0.441 & 108 & 0.533 & 106 \\
\hline Myanmar & 44.720 & 109 & 0.427 & 110 & 0.531 & 107 \\
\hline Iraq & 44.720 & 110 & 0.436 & 109 & 0.573 & 94 \\
\hline Angola & 43.860 & 111 & 0.426 & 111 & 0.551 & 100 \\
\hline Bangladesh & 41.940 & 112 & 0.411 & 113 & 0.539 & 103 \\
\hline East Timor & 41.060 & 113 & 0.415 & 112 & 0.501 & 115 \\
\hline $\begin{array}{l}\text { Syrian Arab } \\
\text { Republic }\end{array}$ & 41.570 & 114 & 0.408 & 114 & 0.502 & 114 \\
\hline Congo & 39.830 & 115 & 0.398 & 115 & 0.526 & 109 \\
\hline Chad & 39.360 & 116 & 0.389 & 116 & 0.478 & 118 \\
\hline South Sudan & 35.340 & 117 & 0.370 & 117 & 0.549 & 102 \\
\hline Libya & 33.440 & 118 & 0.355 & 119 & 0.479 & 117 \\
\hline Yemen & 32.410 & 119 & 0.366 & 118 & 0.501 & 116 \\
\hline $\begin{array}{l}\text { Venezuela } \\
\text { Bolivarian } \\
\text { Republic }\end{array}$ & 30.610 & 120 & 0.323 & 120 & 0.439 & 120 \\
\hline Somalia & 20.040 & 121 & 0.265 & 121 & 0.421 & 121 \\
\hline
\end{tabular}




\subsection{Analysis on empirical results}

\subsubsection{Statistical analysis}

It can be seen from Table 5 that the EDB rankings obtained according to EDB scores issued by the WB are different from those attained by using the traditional TOPSIS method and Mahalanobis distance-based TOPSIS. The better to judge the differentiation of the ranking results obtained through the three methods, the ranking results attained according to WB, traditional TOPSIS method, and Mahalanobis distance-based TOPSIS are shown in Figure 1 where the left and right-hand figures show scatter diagrams for the comparisons of the ranking results obtained through the traditional TOPSIS method and Mahalanobis distance-based TOPSIS with the ranking result issued by the WB, respectively. Furthermore, the Pearson correlation coefficients between the traditional TOPSIS method ranking and Mahalanobis distance-based TOPSIS and the WB's EDB ranking are 0.993 and 0.908 , both of them are statistically significant at the $1 \%$ level.

The WB attained the EDB scores of various countries based on simple additive weighting method by synthesising data pertaining to the aforementioned 10 indicators. The method used by the WB for calculating the EDB scores of various countries ignores the problem of information overlap between various indicators, which can cause certain common information to be overestimated in the evaluation. Additionally, the effect of negative ideal points is ignored, so the ranking result obtained according to the EDB scores will differ from those attained by using the other two methods to some extent. Moreover, the presence of correlation between indicators also results in a significant difference between ranking results acquired through traditional TOPSIS method and Mahalanobis distance-based TOPSIS. Due to having eliminated overlapping information, the Mahalanobis distance-based TOPSIS generally attains a higher level of relative closeness compared with the traditional methods.

As shown in Figure 2, the left-hand figure shows the scatter diagram of the EDB scores and ranking result issued by the WB; the right-hand figure presents the scatter diagram of closeness obtained through use of the traditional TOPSIS method and WB ranking result; furthermore, the Pearson correlation coefficients between EDB score and traditional closeness and WB's EDB ranking are -0.979 and -0.986 , both of them are statistically significant at the $1 \%$ level.

It can be seen from the figure that a country with a lower ranking generally shows a lower EDB score and the relative closeness obtained through the traditional TOPSIS method. Moreover, the discreteness seen in the right-hand figure is higher than that in the left-hand figure. The reason for this is that the traditional TOPSIS method not only considers the distances of indicators of various countries to positive ideal solutions, but also takes into account those to the negative ideal solutions. Furthermore, Figure 3 shows the scatter diagrams of the distances of indicators of various countries to the positive and negative ideal solutions obtained according to the traditional TOPSIS method with the ranking result issued by the WB, respectively. The Pearson correlation coefficients between the positive distance and the negative distance of the traditional TOPSIS method and WB's EDB ranking are 0.318 and -0.344 , both of them are statistically significant at the $1 \%$ level. 

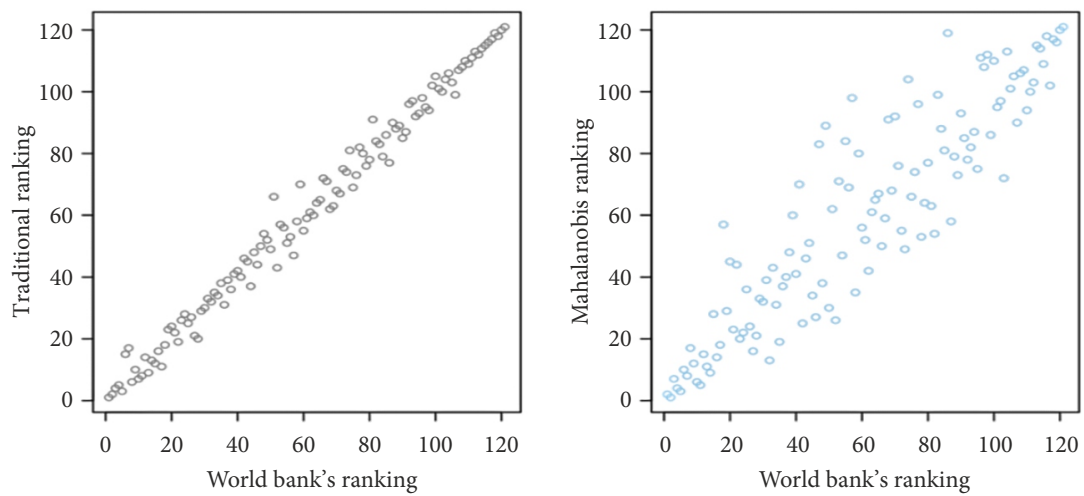

Figure 1. Scatter plot between traditional TOPSIS method ranking \& Mahalanobis distance-based TOPSIS and WB' EDB ranking
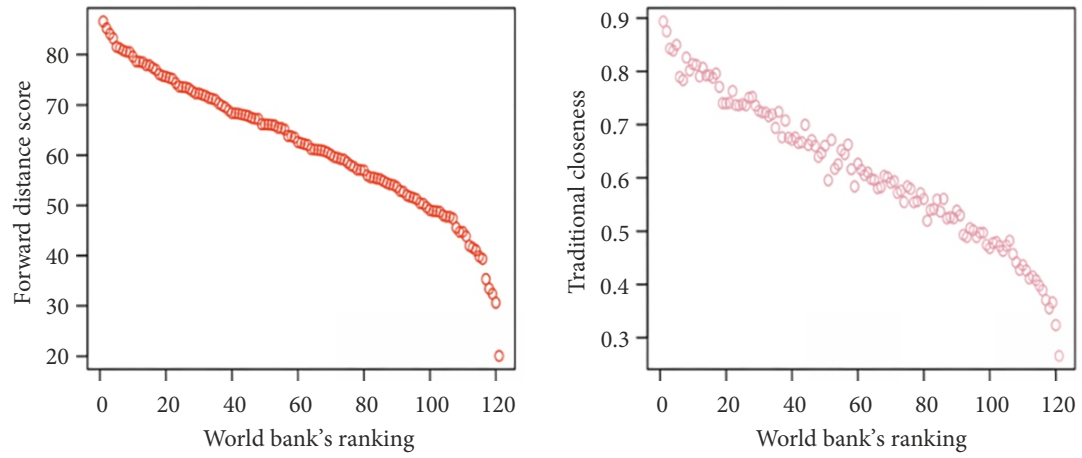

Figure 2. Scatter plot between EDB score \& traditional closeness and WB' EDB ranking
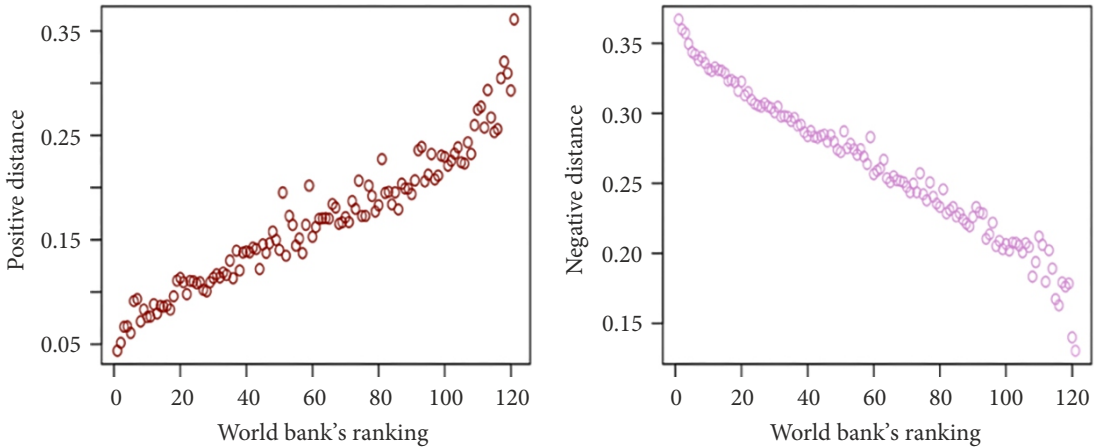

Figure 3. Scatter plot between the positive distance $\&$ the negative distance of traditional TOPSIS method and WB' EDB ranking 
The indicator of a country with a higher ranking issued by the WB is closer to the positive ideal point while further from the negative ideal point: however, the data in Figure 3 still show a certain discreteness. The reason for this is that the ranking provided by the WB only takes the positive ideal solution into account while apart from this, the TOPSIS method also considers the distances of an indicator of various countries to the lowest value of the indicator during ranking. In this way, a better evaluation and ranking result with comparability is attained. The TOPSIS method more sufficiently utilises the raw data and this better reflects the gaps among various countries.

In Figure 4, the left and right-hand figures show the scatter diagrams of the closeness obtained through the traditional TOPSIS method and Mahalanobis distance-based TOPSIS with the ranking result issued by the $\mathrm{WB}$, respectively. The Pearson correlation coefficients between the closeness obtained through the traditional TOPSIS method and Mahalanobis distance-based TOPSIS with the ranking result issued by the WB are -0.986 and -0.897 , both of them are statistically significant at the $1 \%$ level.

The discreteness of the data seen in the right-hand figure is much greater than that in the left-hand figure, which is because the correlation between indicators is taken into account in the right-hand figure. As shown in Table 3, the information overlap between various indicators is significant and correlation between indicators cannot be ignored, therefore, Mahalanobis distance-based TOPSIS can better evaluate the levels of EDB of different countries, the ranking result obtained through the Mahalanobis distance-based TOPSIS is taken as the actual ranking of BRI countries in the present research.

The better to compare differences between the ranking result issued by the WB and the actual ranking result, the ranking result issued by the WB and the actual ranking result are shown on the same scatter diagram (Figure 5). The green scattered points refer to the ranking result issued by the WB while the blue points represent the actual ranking result. The business environments of countries corresponding to the blue scattered points below and above the green scattered point are underestimated and overestimated, respectively. The Pearson correlation coefficient between the EDB ranking results of Mahalanobis distance-based TOPSIS and the WB's EDB ranking is 0.908 , which is statistically significant at the $1 \%$ level.
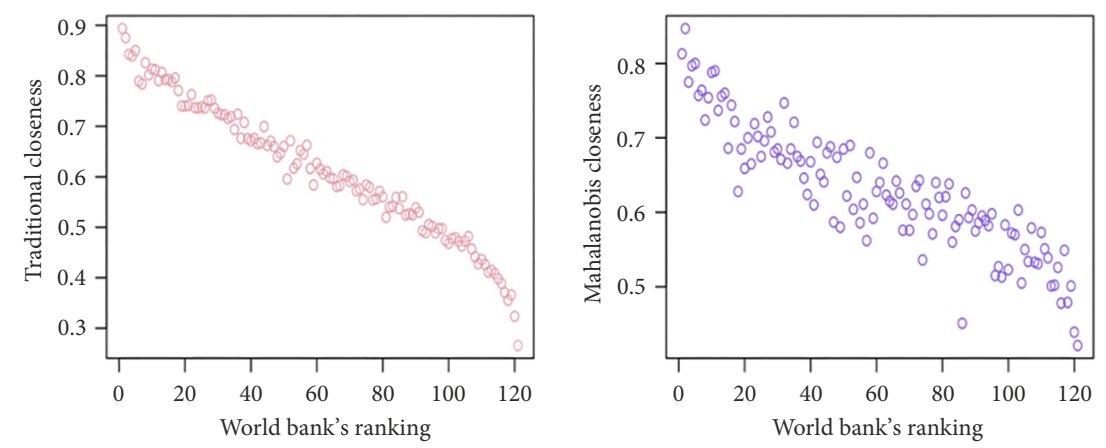

Figure 4. Scatter plot of the closeness obtained through traditional TOPSIS method and Mahalanobis distance-based TOPSIS with the ranking result issued by the WB 


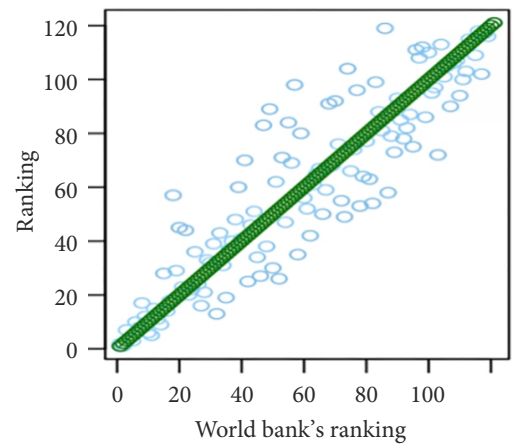

Figure 5. Scatter plot between The EDB ranking results of Mahalanobis distance-based TOPSIS and WB's

EDB ranking
As seen from Figure 5, the results of EDB ranking of most countries issued by the WB differ slightly from the actual results.

According to Table 5 and Figure 5, except for Georgia, Syria, Venezuela, and Somalia, the ranking results of business environments of the other countries are all likely to be either overestimated or underestimated. The rankings of New Zealand and South Korea are overestimated while those of Singapore, Macedonia, etc. are underestimated. There are 53 and 64 countries whose rankings are overestimated and underestimated, respectively: the number of countries whose ranking is underestimated is far larger than that whose ranking is overestimated. The specific conditions are summarised in Table 6 where the gap is obtained by subtracting the actual ranking from the WB's EDB ranking.

Table $6 . \mathrm{EBD}$ is underrated and overrated by the $\mathrm{WB}^{1}$

\begin{tabular}{|l|c|l|c|}
\hline \multicolumn{2}{|c|}{ Overrated } & \multicolumn{2}{c|}{ Underrated } \\
\hline country & gap & \multicolumn{1}{c|}{ country } & gap \\
\hline New Zealand & -1 & Singapore & 1 \\
\hline Korea & -4 & Republic of Macedonia & 4 \\
\hline United Arab Emirates & -4 & Latvia & 6 \\
\hline Lithuania & -1 & Azerbaijan & 2 \\
\hline Malaysia & -9 & Thailand & 5 \\
\hline Estonia & -3 & Kazakhstan & 2 \\
\hline Austria & -3 & Russia & 3 \\
\hline Rwanda & -13 & Turkey & 2 \\
\hline Poland & -1 & China & 2 \\
\hline Czech Republic & -39 & Serbia & 11 \\
\hline Belarus & -10 & Israel & 7 \\
\hline Slovenia & -25 & Montenegro & 3 \\
\hline Armenia & -2 & Chile & 16 \\
\hline Slovakia & -22 & Bulgaria & 17 \\
\hline Moldova & -11 & Morocco & 11 \\
\hline Romania & -4 & Ukraine & 19 \\
\hline Hungary & -2 & Mongolia & 10 \\
\hline Brunei & -8 & Uzbekistan & 20 \\
\hline Croatia & -10 & Oman & 26 \\
\hline Kenya & -1 & Tunisia & 7 \\
\hline Bahrain & -3 & South Africa & \\
\hline Albania & -10 & Malta & \\
\hline & & & \\
\hline
\end{tabular}

$\overline{1}$ The statements "Underrated" and “overrated" here imply the gaps between WB's EDB ranking and actual ranking. 
End of Table 6

\begin{tabular}{|c|c|c|c|}
\hline \multicolumn{2}{|c|}{ Overrated } & \multicolumn{2}{|c|}{ Underrated } \\
\hline country & gap & country & gap \\
\hline Costa Rica & -21 & Samoa & 23 \\
\hline Vietnam & -1 & Uruguay & 4 \\
\hline Kyrgyzstan & -29 & Republic of Seychelles & 9 \\
\hline Greece & -3 & Kuwait & 20 \\
\hline Indonesia & -7 & Djibouti & 2 \\
\hline India & -36 & Dominia & 16 \\
\hline Panama & -40 & Jordan & 8 \\
\hline Bhutan & -11 & Namibia & 1 \\
\hline Qatar & -18 & Antigua and Barbuda & 17 \\
\hline Salvador & -29 & Ghana & 24 \\
\hline Zambia & -13 & Arab republic of egypt & 9 \\
\hline Bosnia & -41 & Cote d'Ivoire & 2 \\
\hline Saudi Arabia & -21 & Tajikistan & 25 \\
\hline Sri Lanka & -1 & Uganda & 15 \\
\hline Dominican Republic & -2 & Islamic Republic of Iran & 3 \\
\hline Trinidad and Tobago & -23 & Cape Verde & 18 \\
\hline Papua New Guinea & -22 & Guyana & 28 \\
\hline Nepal & -5 & Togo & 4 \\
\hline Palestine & -30 & Maldives & 29 \\
\hline Philippines & -19 & Senegal & 9 \\
\hline Mozambique & -16 & Lebanon & 26 \\
\hline Cambodia & -33 & Nigeria & 6 \\
\hline Tanzania & -3 & Grenada & 14 \\
\hline Laos & -15 & Mauritania & 11 \\
\hline Zimbabwe & -11 & Gambia & 7 \\
\hline Bolivia & -14 & Guinea & 20 \\
\hline Algeria & -11 & Ethiopia & 14 \\
\hline Suriname & -9 & Madagascar & 6 \\
\hline East Timor & -2 & Sudan & 5 \\
\hline Chad & -2 & Sierra Leone & 31 \\
\hline \multirow[t]{12}{*}{ Pakistan } & -4 & Cameroon & 4 \\
\hline & & Afghanistan & 1 \\
\hline & & Burundi & 17 \\
\hline & & Gabon & 2 \\
\hline & & Myanmar & 2 \\
\hline & & Iraq & 16 \\
\hline & & Angola & 11 \\
\hline & & Bangladesh & 9 \\
\hline & & Congo & 6 \\
\hline & & South Sudan & 15 \\
\hline & & Libya & 1 \\
\hline & & Yemen & 3 \\
\hline
\end{tabular}


The traditional TOPSIS method or the equal weighted average method adopted by the World Bank repeatedly calculates the common information of the evaluation indicators, which means that the larger the value of the most relevant indicator, the larger the overestimated value of the evaluation result, resulting in a larger ranking gap.

If the absolute value of an overvalued gap in a country exceeds 30 , it means that the country's business environment is seriously overvalued by the World Bank. According to Table 6, the business environments of the Czechia, India, Panama, Bosnia, Palestine, Cambodia, and another six countries are greatly overestimated. Table 4 shows that there is a significant correlation between the indicators. To explore why the business environments of these countries are so overestimated from the perspective of indicators, the average of 10 indicators for the countries that are greatly overrated and moderately estimated is calculated. From Table 7, the average of the indicators of moderately estimated countries is significantly smaller than the average of the countries of severely overrated countries.

Table 7. The means of countries which are largest Underrated and overrated country by WB

\begin{tabular}{|l|c|}
\hline \multicolumn{1}{|c|}{ indicators } & the means of 10 indicators \\
\hline overrated countries & 0.095 \\
\hline moderately estimated countries & 0.084 \\
\hline
\end{tabular}

\subsubsection{Geographic analysis}

In this study, 121 BRI countries are mapped (Figure 6): if a country is labelled in green, the country is a BRI member. If a country is marked in grey, it does not participate in BRI. It can be found from Figure 6 that BRI countries are mostly located in Asia, Africa, and Central and Eastern Europe and their distribution exhibits a significant regional characteristic. The areas of the BRI countries can be divided into nine regions including North East Asia, South East Asia, South Asia, West Asia, Africa, Central and Eastern Europe, Central Asia, South America and New Zealand.

In this section, the ranking result of BRI countries based on EDB scores issued by the WB (hereinafter called the ranking result issued by the WB) is mapped: thereafter, the ranking result of BRI countries acquired by applying Mahalanobis distance-based TOPSIS is described in the map and analysed. Finally, the countries whose rankings are overestimated or underestimated in statistical analyses are presented.

\section{(1) Geographic analysis of the ranking result issued by the WB}

The ranking result issued by the WB obtained above is mapped (Figure 7). The country whose colour is closest to blue has a higher ranking while that closer to red has a lower ranking; grey denotes non-BRI countries. Figure 7 shows that among the BRI countries, New Zealand exhibits the optimal EDB; the EDB of countries in North East Asia, South East Asia, and Central Asia is generally favourable and there is an insignificant difference among various countries within these regions; the EDB of countries in South Asia is at a common level while that in West Asia is significantly different. Countries in Africa generally show a poor EDB and the EDB of countries in the south of Africa is superior to that in the north. There is a favourable EDB for countries in Central and Eastern Europe; the EDB of countries in the south of South America is better than that in the north; the country with the worst EDB is 


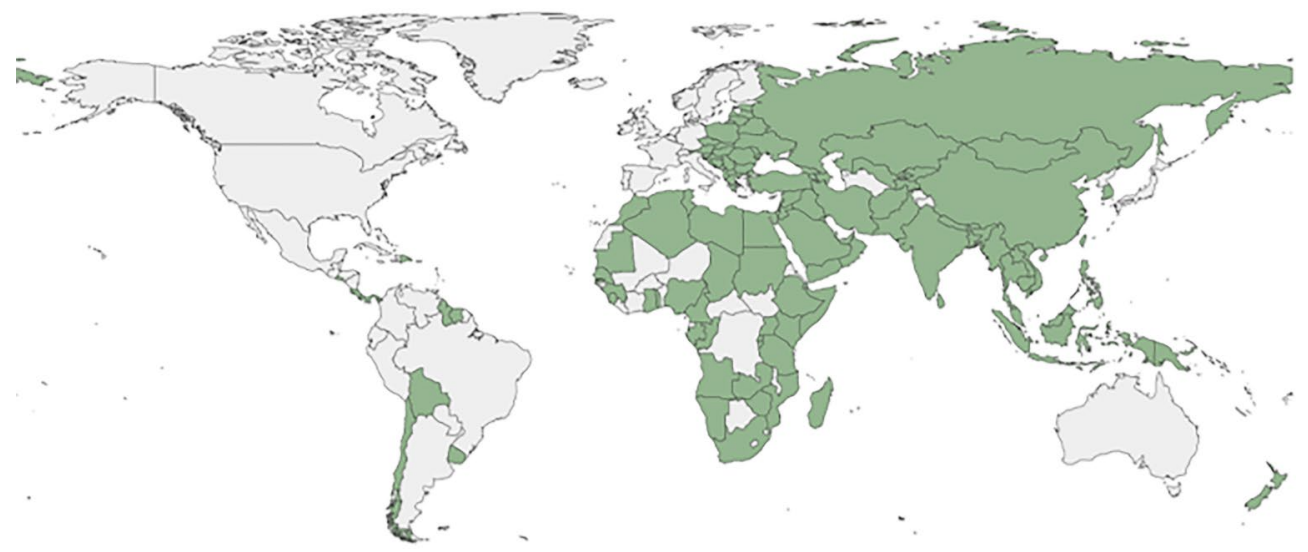

Figure 6. Schematic diagram of the geographical distribution of countries along the Belt and Road

situated in the north of Africa; the EDB of China is dominant among all BRI countries; the countries bordering China exhibit different levels of EDB. On the whole, the EDB of neighbouring countries to the north of China is better than that of those to the south of China.

\section{(2) Geographic analysis of actual ranking result}

The actual ranking result attained above is mapped (Figure 8). The country whose colour is closest to blue has a higher ranking while that closer to red has a lower ranking; grey denotes non-BRI countries. As shown in Figure 8, among BRI countries, countries in North East Asia, South East Asia, Central Asia, and Central and Eastern Europe have a favourable $\mathrm{EDB}$ and insignificant differences exist within these regions. The business environments of countries in South Asia are unfavourable on the whole and their EDB values are significantly different; New Zealand exhibits a favourable EDB; countries in West Asia and Africa generally have a poor EDB, especially countries in North Africa, with insignificant internal differences therein; the EDB of countries in South America shows a great difference, and there are, separately, both high and low levels of EDB in the south and middle of the region. The country with the optimal business environment is located in South East Asia while that with the worst business environment is situated in Africa. The EDB of countries bordering China differs remarkably: the EDB of neighbouring countries to the South West of China is poor while that to the south of China is favourable. The EDB of China is dominant among BRI countries.

\section{(3) Geographic analysis of countries whose EDB ranking is overestimated or underes- timated}

According to Tables 5 and 6, a list is obtained, in which there are 53 and 64 countries with separately overestimated and underestimated EDB and four countries whose EDB values are moderately well estimated. According to the list, all countries are marked in a map to further conduct geographic analysis. The specific distribution of geographical locations of different countries is displayed in Figure 9 where, yellow, blue, and red denote countries whose EDB is underestimated, overestimated and moderately estimated, respectively, and grey represents non-BRI countries. 


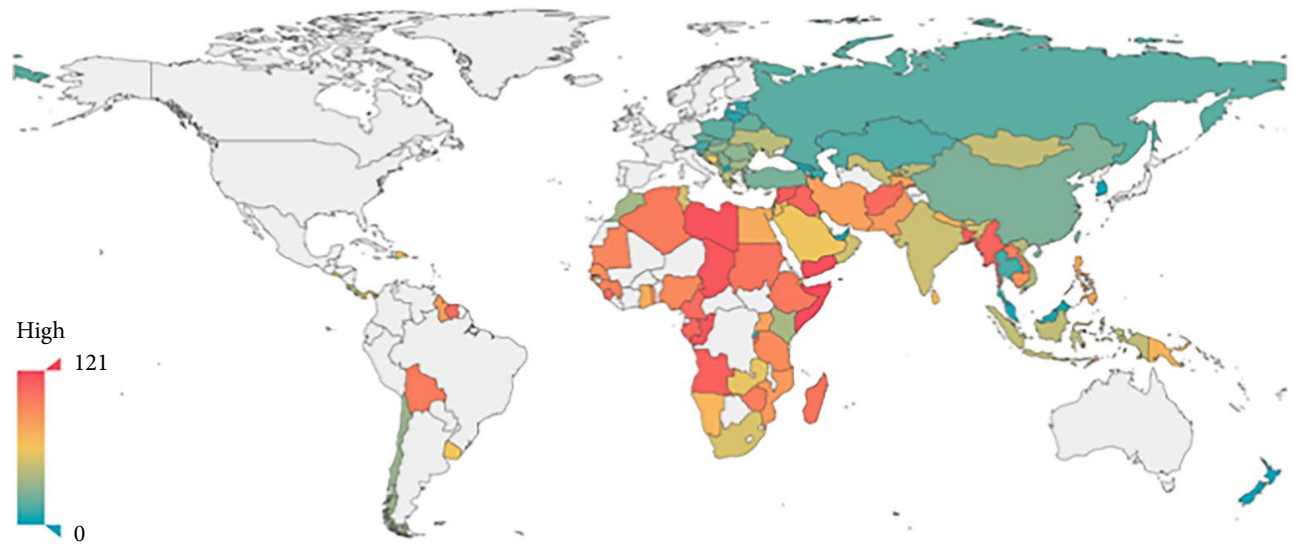

low

Figure 7. Geographic distribution on ranking result issued by the WB

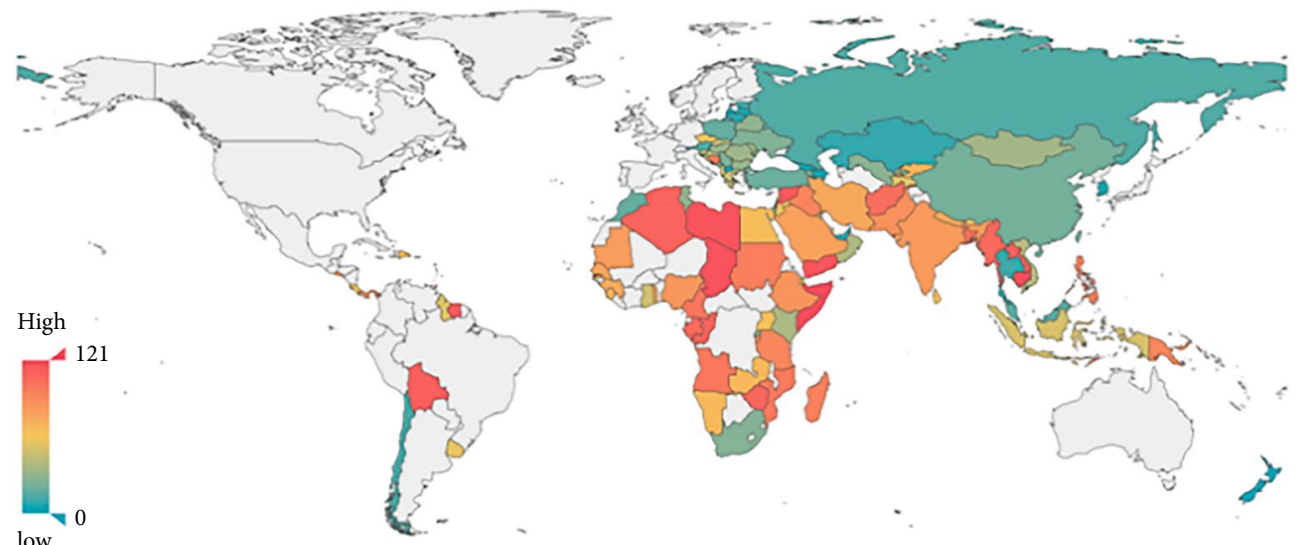

Figure 8. Geographic distribution on actual ranking result

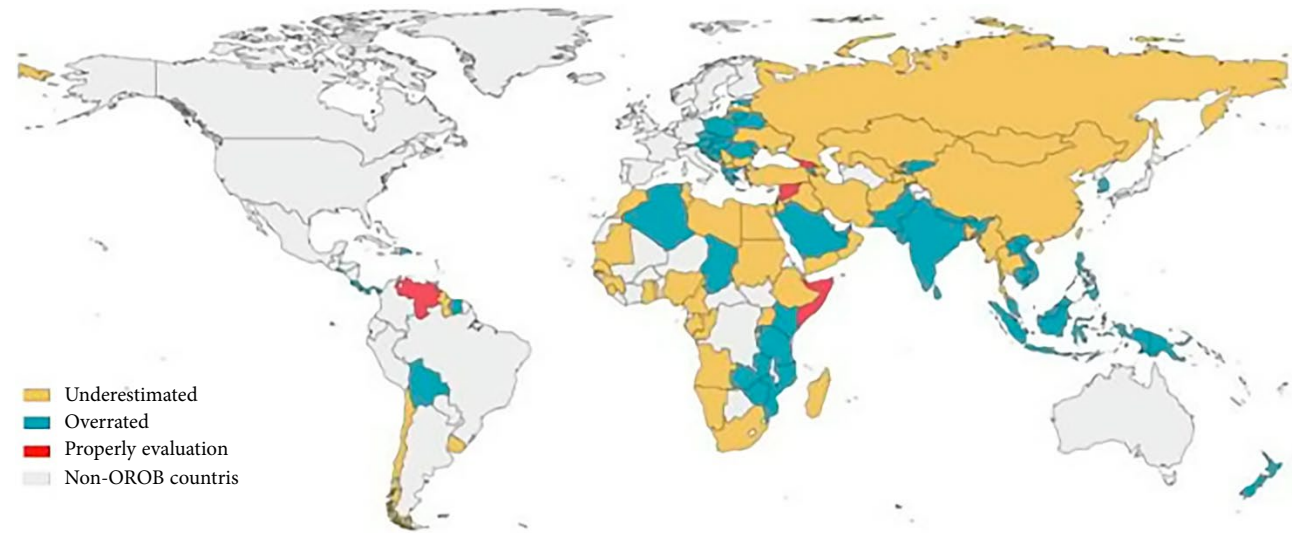

Figure 9. Geographic distribution on the Underrated and overrated country by WB 
As shown in Figure 9, there is significant regional distribution characteristics between the countries whose ranking is overestimated and underestimated: the EDB of countries in North East Asia and Central Asia is generally underestimated while that in South East Asia is commonly overestimated. In South Asia, the proportion of countries whose EDB is underestimated is larger than that of countries whose EDB is overestimated. In West Asia, the proportion of countries whose EDB is overestimated is equivalent to that of countries whose EDB is underestimated. The EDB of New Zealand is overestimated; in Central and Eastern Europe, the proportion of countries whose EDB is overestimated is greater than that whose EDB is underestimated; in Africa, far more countries have underestimated EDB than overestimated EDB. The EDB of countries in the west of Africa is generally underestimated while those in the south east of Africa are commonly overestimated; in South America, the proportion of countries whose EDB is overestimated is equivalent to that with underestimated EDB, in which the EDB of countries in the south is underestimated. According to Table $6,50 \%$ of the countries that are greatly overvalued are in Asia, 33.33\% in Europe, and $16.67 \%$ in North America: this shows that the countries with more repeated indicators have the characteristics of geographical distribution, which directly results in the countries with severe overestimation having regional characteristics.

\section{Conclusions and future work}

The ranking issued by the WB was collected and using the traditional TOPSIS method and Mahalanobis distance-based TOPSIS, the EDB of 121 BRI countries is ranked. Furthermore, the ranking results are analysed from statistical and geographic perspectives, thus drawing the following conclusions:

(1) The ranking results of business environments of various countries obtained by the WB, traditional TOPSIS method, and Mahalanobis distance-based TOPSIS are compared. On this basis, when considering negative ideal points, the traditional TOPSIS method exhibits a ranking result superior to that issued by the WB. Mahalanobis distance-based TOPSIS not only takes negative ideal points into account but also considers the correlation between various indicators, thus yielding a better ranking result than that attained by using the traditional TOPSIS method. That is, among the three ranking results, the ranking result attained by employing Mahalanobis distancebased TOPSIS is closest to the actual situation. Accurate assessment of the business environment is conducive to better investment decisions and more effective government policies. Therefore, the WB is advised to modify their existing method for calculating EDB rankings and EDB scores.

(2) The ranking issued by the WB and actual ranking both exhibit significant regional characteristics. Among BRI countries, New Zealand and countries in North East Asia, Central Asia, South East Asia, and Central and Eastern Europe have a relatively favourable business environment; the business environments of countries in West Asia and Africa are generally unfavourable, having huge potential for improvement. By comparing the ranking result issued by the WB with the actual ranking result, it can be found that countries whose ranking is overestimated and underestimated 
also exhibit remarkable regional characteristics, that is, the business environments of countries in Central and Eastern Europe, New Zealand, etc. are generally overestimated while those in North East Asia, Central Asia, South East Asia, and the south of Africa are underestimated. If the EDB project had been undertaken using the Mahalonobis-TOPSIS method at an earlier juncture, it will enable companies to make better investment decisions and reduce the investment losses caused by erroneous assessment of the prevailing business environment. On the other hand, it will prompt government to formulate policies related to the business environment that are more suitable for the country.

(3) Evaluating EDB as an MCDM problem should maintain the convention of solving MCDM problems, which consists of measurement, weighting, and evaluation: this may be extended to forecasting and risk analysis, so future work should include building reasonable and reliable models to improve evaluation of EDB weighting, forecasting, and risk analysis. On the other hand, future work should introduce possible uncertainties such as the China-US trade dispute into the model.

\section{Acknowledgments}

The authors are grateful to the editors and the anonymous reviewers for their insightful comments and suggestions. This research is supported by the Humanities and Social Science Foundation of Ministry of Education of China (Grant No. 18YJC630130).

\section{References}

Antuchevičienė, J., Zavadskas, E. K., \& Zakarevičius, A. (2010). Multiple criteria construction management decisions considering relations between criteria. Technological and Economic Development of Economy, 16(1), 109-125. https://doi.org/10.3846/tede.2010.07

Bai, C., \& Sarkis, J. (2018). Integrating sustainability into supplier selection: a grey-based TOPSIS analysis. Technological and Economic Development of Economy, 24(6), 2202-2224. https://doi.org/10.3846/tede.2018.5582

Belt and Road Portal. (n.d.). https://www.yidaiyilu.gov.cn/index.htm

Chang, C. H., Lin, J. J., Lin, J. H., \& Chiang, M. C. (2010). Domestic open-end equity mutual fund performance evaluation using extended TOPSIS method with different distance approaches. Expert Systems with Applications, 37(6), 4642-4649. https://doi.org/10.1016/j.eswa.2009.12.044

Corcoran, A., \& Gillanders, R. (2015). Foreign direct investment and the ease of doing business. Review of World Economics, 151, 103-126. https://doi.org/10.1007/s10290-014-0194-5

Cui, H. Y. (2016). Study on the trade \& investment facilitation evaluation index system of countries of "one belt and one road". Journal of International Trade, 9, 153-164.

Cullinane, K., Lee, P., Yang, Z., \& Hu, Z. (2018). Editorial: China's Belt and Road initiative. Journal of Asian Economics, 117, 1-4.

dos Santos, B., Godoy, L., \& Campos, L. (2019). Performance evaluation of green suppliers using entropy-TOPSIS-F. Journal of Cleaner Production, 207, 498-509.

https://doi.org/10.1016/j.jclepro.2018.09.235 
Du, J., \& Zhang, Y. (2018). Does One Belt One Road initiative promote Chinese overseas direct investment? China Economic Review, 47, 189-205. https://doi.org/10.1016/j.chieco.2017.05.010

Dwivedi, G., Srivastava, R., \& Srivastava, S. (2018). A generalised fuzzy TOPSIS with improved closeness coefficient. Expert Systems with Applications, 96, 185-195. https://doi.org/10.1016/j.eswa.2017.11.051

Escaleras, M., \& Chiang, E. (2017). Fiscal decentralization and institutional quality on the business environment. Economics Letters, 159, 161-163. https://doi.org/10.1016/j.econlet.2017.07.019

González-Arteaga, T., Alcantud, C., \& Calle, R. (2016). A cardinal dissensus measure based on the Mahalanobis distance. European Journal of Operational Research, 251, 575-585. https://doi.org/10.1016/j.ejor.2015.11.019

Gupta, H. (2018). Assessing organizations performance on the basis of GHRM practices using BWM and Fuzzy TOPSIS. Journal of Environmental Management, 226, 201-216. https://doi.org/10.1016/j.jenvman.2018.08.005

Hamill, P., Giordano, M., Ward, C., Gile,s D., \& Holben, B. (2016). An AERONET-based aerosol classification using the Mahalanobis distance. Atmospheric Environment, 140, 213-233. https://doi.org/10.1016/j.atmosenv.2016.06.002

Huang, Y. (2019). Environmental risks and opportunities for countries along the Belt and Road: Location choice of China's investment. Journal of Cleaner Production, 211, 14-26. https://doi.org/10.1016/j.jclepro.2018.11.093

Hwang, C. L.; Lai, Y. J., \& Liu, T. Y. (1993). A new approach for multiple objective decision making. Computers and Operational Research, 20(8): 889-899. https://doi.org/10.1016/0305-0548(93)90109-V

Hwang, C. L., \& Yoon, K. (1981). Multiple attribute decision making: Methods and applications. Springer. https://doi.org/10.1007/978-3-642-48318-9

Jiang, Y., Zhang, J., Asante, D., \& Yang, Y. (2019). Dynamic evaluation of low-carbon competitiveness (LCC) based on improved Technique for Order Preference by similarity to an Ideal Solution (TOPSIS) method: A case study of Chinese steelworks. Journal of Cleaner Production, 217, 484-492. https://doi.org/10.1016/j.jclepro.2019.01.054

Ke, T., Lv, H., Sun, M., \& Zhang, L. (2018). A biased least squares support vector machine based on Mahalanobis distance for PU learning. Physica A: Statistical Mechanics and its Applications, 509, 422-438. https://doi.org/10.1016/j.physa.2018.05.128

Khan, B., Bilal, R., \& Young, R. (2018). Fuzzy-TOPSIS based Cluster Head selection in mobile wireless sensor networks. Journal of Electrical Systems and Information Technology, 5, 928-943. https://doi.org/10.1016/j.jesit.2016.12.004

Kong, Q., \& Dong, H. (2015). Trade facilitation and trade potential of countries along "One Belt One Road" route. Journal of International Trade, 12, 158-168.

Li, J., Liu, B., \& Qian, G. (2019). The belt and road initiative, cultural friction and ethnicity: Their effects on the export performance of SMEs in China. Journal of World Business, 54, 350-359. https://doi.org/10.1016/j.jwb.2019.04.004

Lu, W., \& Chen, W. (2018). Business environment, technological innovation and dynamic change of comparative advantage. International Economics and Trade Research, 11, 61-77.

Ouenniche, J., Pérez-Gladish, B., \& Bouslah, K. (2018). An out-of-sample framework for TOPSIS-based classifiers with application in bankruptcy prediction. Technological Forecasting and Social Change, 131, 111-116. https://doi.org/10.1016/j.techfore.2017.05.034

Pelegrina, G., Duarte, L., \& Romano, J. (2019). Application of independent component analysis and TOPSIS to deal with dependent criteria in multicriteria decision problems. Expert Systems with Applications, 122, 262. https://doi.org/10.1016/j.eswa.2019.01.008 
Piwowarski, M., Miłaszewicz, D., Łatuszyńska, M., Borawski, M., \& Nermend, K. (2018). TOPSIS and VIKOR methods in study of sustainable development in the EU countries. Procedia Computer Science, 126, 1683-1692. https://doi.org/10.1016/j.procs.2018.08.109

Qu, Z., \& Yang, B. (2017). The influence of system quality of the countries along the "Belt and Road" on China's foreign direct investment. Research on Economics and Management, 11, 15-21.

Shrestha, M. (2017). Cooperation on finance between China and Nepal: Belt and Road initiatives and investment opportunities in Nepal. The Journal of Finance and Data Science, 3, 31-37. https://doi.org/10.1016/j.jfds.2017.09.004

Sirisawat, P., \& Kiatcharoenpol, T. (2018). Fuzzy AHP-TOPSIS approaches to prioritizing solutions for reverse logistics barriers. Computers \& Industrial Engineering, 117, 303-318. https://doi.org/10.1016/j.cie.2018.01.015

Sun, L., Miao, C., \& Yang, L. (2017). Ecological-economic efficiency evaluation of green technology innovation in strategic emerging industries based on entropy weighted TOPSIS method. Ecological Indicators, 73, 554-558. https://doi.org/10.1016/j.ecolind.2016.10.018

Tang, H., Shi, Y., \& Dong, P. (2018). Public blockchain evaluation using entropy and TOPSIS. Expert Systems with Applications, 117, 204-210. https://doi.org/10.1016/j.eswa.2018.09.048

The World Bank. (2018). Doing Business 2019: Training for Reform. The World Bank Group, Washington DC. https://www.doingbusiness.org/content/dam/doingBusiness/media/Annual-Reports/English/ DB2019-report_web-version.pdf

Vidal, R., \& Sánchez-Pantoja, N. (2019). Method based on life cycle assessment and TOPSIS to integrate environmental award criteria into green public procurement. Sustainable Cities and Society, 44, 465-474. https://doi.org/10.1016/j.scs.2018.10.011

Walczak, D., \& Rutkowska, A. (2017). Project rankings for participatory budget based on the fuzzy TOPSIS method. European Journal of Operational Research, 260, 706-714. https://doi.org/10.1016/j.ejor.2016.12.044

Wang, Z., Hao, H., Gao, F., Zhang, Q., Zhang, J., \& Zhou, Y. (2019). Multi-attribute decision making on reverse logistics based on DEA-TOPSIS: A study of the Shanghai end-of-life vehicles industry. Journal of Cleaner Production, 214, 730-737. https://doi.org/10.1016/j.jclepro.2018.12.329

Wang, Z., Li, D., \& Zheng, H. (2018). The external performance appraisal of China energy regulation: An empirical study using a TOPSIS method based on entropy weight and Mahalanobis distance. International Journal of Environmental Research and Public Health, 15, 235-251. https://doi.org/10.3390/ijerph15020236

Wang, Z., \& Wang, Y. (2014). Evaluation of the provincial competitiveness of the Chinese high-tech industry using an improved TOPSIS method. Expert Systems with Applications, 41, 2824-2831. https://doi.org/10.1016/j.eswa.2013.10.015

Xu, Y., Cui, R., \& Bao, Y. (2015). Influence factors of Russian regional investment environment that improve level of FDI inflow: Based on dynamic panel analysis estimated by system GMM method. International Business, 06, 57-113.

Yan, Z., Zhu, J., Fan, D., \& Kalfadellis, P. (2018). An institutional work view toward the internationalization of emerging market firms. Journal of World Business, 53, 682-694. https://doi.org/10.1016/j.jwb.2018.03.008

Yoon, K. (1987). A reconciliation among discrete compromise situations. Journal of the Operational Research Society, 38(3), 277-286. https://doi.org/10.1057/jors.1987.44

Yoon, K., \& Kim, W. (2017). The behavioral TOPSIS. Expert Systems with Applications, 89, 266-272. https://doi.org/10.1016/j.eswa.2017.07.045

Yue, X., \& Qian, X. (2015). Investment environment comparison in five Central Asian countries. Asiapacific Economic Review, 02, 73-78. 
Zareie, A., Sheikhahmadi, A., \& Khamforoosh, K. (2018). Influence maximization in social networks based on TOPSIS. Expert Systems with Applications, 108, 96-107.

https://doi.org/10.1016/j.eswa.2018.05.001

Zeng, S. Z., Chen, S. M., \& Fan, K. Y. (2020a). Interval-valued intuitionistic fuzzy multiple attribute decision making based on nonlinear programming methodology and TOPSIS method. Information Sciences, 506, 424-442. https://doi.org/10.1016/j.ins.2019.08.027

Zeng, S. Z., Luo, D. D., Zhang, C. C., \& Li, X. S. (2020b). A correlation-based TOPSIS method for multiple attribute decision making with single-valued neutrosophic information. International Journal of Information Technology \& Decision Making, 19(01), 343-358. https://doi.org/10.1142/S0219622019500512

Zeng, S. Z., \& Xiao, Y. (2018). A method based on TOPSIS and distance measures for hesitant fuzzy multiple attribute decision making. Technological and Economic Development of Economy, 24(3), 969-983. https://doi.org/10.3846/20294913.2016.1216472

Zhong, F., \& Fan, S. (2016). Investment climate assessments, East Asian development and the great recession of neo-liberalism: The case of the World Bank Doing Business Report. Journal of Contemporary Asia - Pacific Studies, 30, 118-159. 